\title{
Könyvszemle
}

SIPOS JÚLIA GONDOZÁSÁBAN

\section{KULTÚRAKÖZVETÍTÉSI FOLYAMATOK A KORA ÚJKORI KÖZÉP-EURÓPÁBAN}

Az utóbbi évtizedek nemzetközi irodalom- és müvelődéstörténeti kutatásában szembeötlő módon előtérbe került az interdiszciplinaritás és a komparatisztika szemléletmódja, újabb eredményeket elsősorban a rokontudományok együttesét megmozgató és a különböző nemzeti jelenségeket egymással összevető és együtt tárgyaló módszerek hoztak. Az egyes európai régiók, nyelvek és kultúrák közötti kapcsolatok, párhuzamok, müveltségközvetítő folyamatok feltérképezése gyakran új kérdésirányokat nyitott meg, s ezzel módosítani tudta a korábbi ismereteket, irodalmi kánonokat, korszakjellemző sztereotípiákat. Ezeknek a szempontoknak az érvényesítése különösen a kora újkori magyarországi irodalom- és művelődéstörténet jelenségeinek korszerü értelmezésében vált indokolttá, minthogy ekkor még igen szoros összefüggések mutatkoztak latinitás és nemzeti nyelv, szöveg és kép (textus és imago), hitélet és énekkultúra között, s a korszak mentalitását csak mindezek együttes vizsgálata révén lehet autentikusan bemutatni. Az ilyen szemléletű kutatómunkában már évtizedek óta kiemelkedő teljesítményt mutat a Tüskés Gábor-Knapp Éva szerzőpáros, mivel a magyar jelenségeket közép-európai összefüggéseikkel térképezik fel. Nemzetközi rangú könyvkiadóknál közzétett német és angol nyelvü köteteik eredményei mindinkább beépülnek a külhoni tudományos élet vérkeringésébe, $\mathrm{s}$ ezáltal a magyar jelenségek európai kontextusban jelenhetnek meg.

Korábbi kötetük ma már alapvető tétel a nemzetközi irodalom- és kegyességtörténeti szakirodalomban (Volksfrömmigkeit in Ungarn, Dettelbach, 1996). Ezt követően jelent meg Tüskés Gábornak a 17. századi magyar elbeszélő irodalom európai kapcsolatairól szóló monográfiája (Johannes Nádasi, Tübingen, 2001), amely komparatív módszerrel mutatta be a barokk korszak kevéssé ismert, ámde rendkívül termékeny magyar szerzőjének írói aktivitását és kiadványainak európai összefüggésrendszerét. A szerzőpáros újabb impozáns tanulmánykötete (Germania Hungaria Litterata. Deutsch-ungarische Literaturverbindungen in der frühen Neuzeit, Berlin, 2008) a kora újkori magyar-német irodalmi kapcsolatok és párhuzamok köréből tizenkét tanulmányt adott közre, köztük a neolatin költészetről, irodalomelméleti kompendiumokról, emblematikáról, német jezsuita 
drámák magyar témáiról szóló írásokat. Tüskés Gábor társszerkesztésével azonos koncepció jegyében jelent meg több idegen nyelvű tanulmánygyüjtemény és konferenciakötet is (Das Ungarnbild, 2005; Militia et Litterae, 2009; Fortunatus, Melusine, Genovefa, 2010; Literaturtransfer und Interkulturalität, 2012).

A münsteri Westfälische Wilhelms-Universität rangos könyvsorozatában újabban megjelent vaskos kötet (Litterae Hungariae, 2018) több tekintetben folytatása korábbi kutatásaiknak, $\mathrm{s}$ ismét termékeny hozzájárulás a modern kort megelőző időszak közép-európai műveltségi összképének, ezen belül főleg kultúraforgalmazási eljárásainak feltérképezéséhez. A könyv tizenhét tanulmánya öt nagyobb tematikai egységben tárgyalja azokat a müfajokat, intellektuális kapcsolatokat, kommunikációs csatornákat, amelyek révén a magyarországi irodalmi és kulturális értékek az európai szellemi közeghez kapcsolódtak. Ezúttal e gazdag anyagból a tematikus blokkok néhány jellemző eredményének méltatására vállalkozhatunk.

Az első témakör a magyar-német irodalmi kapcsolatok különféle kérdéseit tárgyalja. Ilyen a legkorábbi német prózaregénynek, a késő középkori eredetű Fortunatusnak a magyarországi recepciótörténete, aminek különlegessége, hogy a német münek két magyar nyelvü feldolgozása is készült, de egymástól merőben különböző korszakokban és müfajokban. Az egyik még 1580 körül, verses formában jelent meg, moralizáló tendenciájával is kapcsolódva a históriás ének hazai hagyományához, a másik viszont mintegy hetven év múlva, 1651-ben Lőcsén prózai változatban került ki a nyomdából. Később számos változata formálódott ki, jelezve a téma népszerűségét. A tanulmány gondos filológiai kutatómunkával követi a téma hagyományozódását, a különböző kontextusokba kerülő történet sorsát, mesetradíciót alakító szerepét, folklór szövegváltozatainak útját, azt a transzformációs folyamatot, amely a nyelvi határokat átlépve gazdagított több regionális kultúrát is.

Ezt követően a német irodalom magyarságképét még két további tanulmány árnyalja. Közülük az egyik Daniel Speer közismert műve, a Simplicissimus (1683) alapján teszi ezt, s ennek révén a Grimmelshausen-hatás érvényesülését is regisztrálja. A másik a historia litteraria 18. századi magyarországi képviselőinek (David Czvittinger, Mihály Rotarides, Martin Schmeizel) német ismertségét és megítélését tekinti át. Ebben a blokkban mind filológiai, mind lelkiségtörténeti újdonságnak számít a Martin von Cochem kapucinus szerzetes imádságoskönyvének (Gertrudenbuch) magyar fordítását (Ágoston Péter: Mennyei követek, 1681) bemutató elemzés, amely a délnémet egyházi próza kiemelkedő képviselőjének recepcióját kíséri figyelemmel. A német szerzetest a poszttridentinus szellem képviselőjének, a lelki élet megújítójának, a nép misszionáriusának nevezték, őt tartották a német nyelvterület legolvasottabb vallásos írójának a kortársak. Müveit számos nyelvre lefordították, az általa közvetített „,compassio poétikája” ezek szerint igen népszerủ áhítati kiadványt jelentett, s a fordítás - pontosabban: szabad átdolgozás - a magyar spirituális nyelv lehetőségeit is gazdagította. 
A második tematikus egység három írása a neolatin irodalom köréből mutat be egy-egy olyan müfajt, amelynek kézikönyvei német és magyar nyelvterületen egyaránt elterjedtek, és jelentős kulturális hatást fejtettek ki. A magyarországi retorikatörténet például korábban csak nagyon kevés figyelmet szentelt Matthaeus Tympius (1566-1616) münsteri katolikus retorikatanár hatásának felmérésére, holott praeceptumainak, különféle tankönyveinek és ájtatossági müveinek erős jelenléte kimutatható a kora újkori könyvjegyzékekből, amelyek még azt is tanúsítják, hogy recepciója interkonfesszionális jellegü volt, tehát az oktatás érdeke olykor felülírta a felekezeti szempontokat.

A továbbiakban impozáns tanulmány méri fel a kor levélírásának elméleteit, az episztolográfia latin nyelven közkinccsé tett teóriáit. Részletesen kidolgozott szabályok határozták meg a humanista levélírás elveit, Ciceró alapján Erasmus, Lipsius, Vives és más neves tudósok fejtegetései rögzítették azokat, a Kárpát-medencében pedig elsősorban a jezsuita oktatásban, a grammatikai és retorikai képzésben kaptak helyet az episztolaírás szabályai. Az elemzés sorra veszi a témának a régiónkban használt müveit (Masen, Balbin, Forti, Worpitz munkái a legfontosabbak), ezekből mutatkozik meg a kor levélírási kultúrájának jellege. A közép-európai kulturális transzfer egy további területe az iskolai színjátszás, minthogy német és magyar nyelvterületen egyaránt szereplő témák mutathatók ki a források alapján. Érthető, hogy Közép-Európa iskolai színpadjain (Bécs, München, Dillingen, Würzburg, Augsburg) a magyar történelmi témák közül miért éppen a Szent Istvánnal foglalkozó darabok kerültek túlsúlyba: a kereszténységet meghonosító uralkodó ugyanis érthető módon vonzotta az ottani befogadó közeget, a többi magyar téma (III. Béla, Hunyadiak) előfordulása szórványos.

Újabb koherens témakört jelent a kötetben a szöveg és kép (Text und Bild) együttes hatását alkalmazó kiadványok elterjedésének útvonalait feltérképező fejtegetések együttese. Filológiai bravúrnak számít Rimay János erény-versének új szempontú elemzése, ikonográfiai forrásának azonosítása: Jakob de Zetter emblémáskönyvében talált rá a kutatói figyelem arra a metszetre, amelyiken az ún. „összeláncolt erények” (virtutes concathenatae) láthatóak, a magyar költő tehát jól ismerte a nemzetközi forgalomban elterjedt müvet. Itt kapott helyet a két Zrínyi Miklós ikonográfiáját tárgyaló tanulmány is, amely gazdag képanyag kíséretében mutatja meg a német kulturális kontextusban megmutatkozó Zrínyi-recepció vizuális formában megjelenített változatait. Ugyancsak jól válogatott képanyag kíséri a témakör további tanulmányait, a győri jezsuita kollégium díszlépcsőházának freskóciklusáról szólót, valamint a jezsuita szentek emblematikus biográfiáit tárgyalót, mindkét téma beszédes példája az ikonográfiai motívumok, képzőművészeti toposzok vándorlásának, cserélódésének, regionális variálódásának, a szakrális kapcsolatok kultúrateremtő hatásának.

A kötet negyedik tematikus egysége az elbeszéléskutatás (Erzählforschung) körébe tartozó három tanulmányt foglalja magába. Az első a reformáció jubile- 
umi évéhez kapcsolódó nagy ívü áttekintés, az elbeszélő irodalom és a hitújítási mozgalmak kapcsolatára vonatkozó frissebb nemzetközi (fóként német és magyar) szakirodalom eredményeinek számbavétele. Az irodalomtörténeti nézőpont mellett itt különösen is érvényesül az interdiszciplinaritás elve: a retorikai és narratológiai szemlélet mellé társítva a történeti-folklorisztika terminológiáját, így több tudományág együttes figyelembevétele hitelesíti a következtetéseket.

Hálás téma a kötet célkitűzése számára Mikes Kelemen leveleskönyvének forráskutatása, amelyből kiderül a rodostói számüzött széles körủ európai irodalmi tájékozottsága, a kulturális transzfer sokrétüsége. Ugyanakkor arra is okkal figyelmeztetnek a szerzők, hogy a konkrét forrás vagy előkép (Vorlage) sokszor csak nagy óvatossággal jelölhető meg (vagy még úgy sem), mivel az egyes motívumok számos variációban fordultak elő a különböző nyelvủ írott és szóbeli hagyományozódásban.

A kötetet záró ötödik témakör három tanulmánya kora újkori irodalmi szövegek kegyességtörténeti vonatkozásait tárgyalja, többnyire német-magyar kontextusban mutatva be a magyar jelenségeket. Kitünik ebből, hogy a német kultúrtörténeti, kulturális antropológiai szakirodalomban jelentékeny pozíciót elfoglaló témakör (Frömmigkeitsliteratur) magyar változatainak feldolgozása elengedhetetlen az európai összkép arányos kialakításához.

A Tüskés-Knapp-szerzőpáros kutatói módszere a szigorú szövegközpontú elemzést egyesíti az eszmetörténet szempontjaival, megállapításaik minden esetben szilárd filológiai alapokra épülnek, következtetéseik a kora újkori ember önértelmezésének, gondolkodási mechanizmusainak, mentalitásának jobb megismeréséhez járulnak hozzá. Ez a szemlélet megköveteli a komparatív irodalomtudomány, a történeti elbeszéléskutatás és a spiritualitástörténet módszeres együttmüködését, és jelentős mértékben inspirálja a kelet-közép-európai irodalmi régiók új eredményeinek növekvő mértékủ integrációját a nemzetközi kutatás körképébe.

(Éva Knapp und Gábor Tüskés: Litterae Hungariae. Transformationsprozesse im europäischen Kontext (16.-18. Jahrhundert), Münster, 2018, MV Wissenschaft, S. 592 [Wissenschaftliche Schriften der WWU Münster, Reihe XII, Band 20.])

Bitskey István az MTA rendes tagja, professor emeritus Debreceni Egyetem 


\section{A „SZÉP AKASZTOTT" MINISZTERELNÖK}

A párizsi szalonok hölgytársasága által egykoron csak „szép akasztott ember”-nek nevezett idősebb gróf Andrássy Gyuláról magyar nyelven utoljára 1941-ben jelent meg életrajz, a 20. század első felének jeles történésze, Angyal Dávid tollából. Közel nyolc évtizeddel később Kozári Monika a dualizmus korának ismert és elismert kutatója vállalkozott arra, hogy Andrássy Gyula címmel monográfiát írjon a grófról, akit müvében igazi államférfinak, a polgári Magyarország egyik megteremtőjének nevez.

Az igényes kivitelezésű kötet borítójáról Benczúr Gyula Andrássy-portréja tekint vissza ránk, a könyv végén található képmellékletben pedig további Andrássyt ábrázoló vagy hozzá kapcsolódó festmények, rajzok, karikatúrák, illetve dokumentumok kaptak helyet. A szerző munkájában elsősorban a gróf magyar miniszterelnöki tevékenységére (1867-1871) koncentrált, s emiatt a biográfia „hősének" gyermek- és ifjúkora, 1849-es diplomáciai küldetése Konstantinápolyban, a szabadságharc leverését követő párizsi emigrációja vagy az osztrák-magyar közös külügyminiszteri megbízatása (1871-1879) kevésbé hangsúlyosan jelennek meg a müben.

Kozári a könyvében számos Andrássy-idézetet használt fel, mivel az volt a célja, hogy öt „,beszéltetve” ismerje meg az olvasó, miként is gondolkodott a kormányfő. $\mathrm{S}$ bár olykor a hosszabb idézeteket, véleményünk szerint, érdemesebb lett volna inkább rövidebben, a szerző saját szavaiban összegezni, mégsem állíthatjuk azt, hogy a kötet írója kerülte volna a nyílt, személyes állásfoglalásokat Andrássyt illetően.

Az olvasmányos stílusban készült életrajzból megtudhatjuk, hogy a majdani kiegyezés gondolata már 1850 őszén foglalkoztatta a grófot, aki egy neves londoni folyóiratban amellett érvelt, hogy Ausztria csak akkor lenne képes az európai hatalmi egyensúlyban ellenpontot képezni Oroszországgal szemben, ha szakítana az 1849 utáni birodalmi centralizációval, nemzeti igényeinek teljesítésével helyreállítva Magyarország függetlenségét. Hasonló nézeteket képviselt azt követően is, hogy 1857-ben hazatért Franciaországból (példának okáért 1865-ben úgy fogalmazott, hogy a Habsburg Monarchia abban az esetben lehet ismét számottevő befolyással bíró tényező a kontinensen, ha a birodalom mindkét fele „saját formái szerint, de egyaránt szabad és alkotmányos" lesz), így nem meglepő, hogy az egyik legbizalmasabb politikai elvbarátja lett Deák Ferencnek, a kiegyezés szellemi atyjának. Ök ketten magánemberként is jól megértették egymást, és „,a haza bölcse" igen jó véleménnyel volt Andrássy intellektuális képességeiről, politikai tehetségéröl. 
A kiegyezési tárgyalások lezárulta után Deák Andrássyt ajánlotta maga helyett magyar miniszterelnöknek. A négy évig és nyolc hónapig az ország élén álló gróf kormányföségének mérlege Kozári értékelése szerint egyértelműen pozitív. Ekkor született meg az osztrák (1867) és a horvát (1868) kiegyezés, rendeződött a közös államadósság ügye - amit Ausztria még a neoabszolutizmus időszakában vett fel -, létrejött Erdély uniója az anyaországgal, elindult a katonai határôrvidék közigazgatásának magyar jogrend szerinti átszervezése, és megvalósult a hatalmi ágak szétválasztása is. Mindezeken túl báró Eötvös József vallás- és közoktatásügyi miniszter elgondolásai alapján a parlament 1868-ban fogadta el a népiskolai törvényt, továbbá még ugyanabban az esztendőben a nemzetiségi törvényt. Andrássy eltökélt szándéka volt Pest-Budát igazi fővárossá alakítani, s ezért nagy súlyt fektetett a város fejlesztésére, 1870-ben pedig a kezdeményezésére alapították meg a Fővárosi Közmunkák Tanácsát. Kiállt a magyar zsidóság emancipációja, a közös hadsereg intézménye, valamint a dualista rendszer mellett, amelyet ö ,nem könnyen felszedhető nomád sátornak” tekintett, hanem egy olyan megoldásnak, amivel alkotói tartósan rendezni kívánták a közjogi kérdéseket.

Kozári Monika szerint Andrássy és a magyar politikusok zömének szemlélete között döntő különbség volt, hogy a gróf külpolitikus volt, aki birodalomban gondolkodott. Éppen ezért hiányérzetünk támadhat, hogy a kötet Andrássy közös külügyminiszterségét alig három és fél oldalban tárgyalja. Mindenképpen jobb lett volna ennek, az Andrássy élete szempontjából igen jelentős időszaknak nagyobb teret szentelni a müben. Már csak azért is, mert a szerző vitathatatlanul sikeresnek ítélte meg a gróf ebbéli tevékenységét. Andrássy külpolitikai céljai között Törökország balkáni helyzetének stabilizálása szerepelt az oroszok ellenében, illetve Németország szövetségének elnyerése. Amikor felismerte, hogy az 1873-ban megkötött három császár (német, orosz, osztrák) egyezménye ellenére Németország és Oroszország kapcsolatai elhidegülőben voltak, örömében állítólag háromszor is kézen állt Metternich kancellár egykori íróasztalán. A balkáni viszonyokat rendező 1878 -as berlini kongresszus kétségkívül a gróf külügyi pályájának csúcsa, míg a rákövetkező évben Németországgal aláírt kettős szövetség a külügyminiszteri törekvéseinek beteljesülését jelentette.

Ugyanakkor függetlenül azon meglátásunktól, hogy idősebb gróf Andrássy Gyula közös külügyminiszterségét e könyvben indokolt lett volna bővebben kifejteni, úgy hisszük, hogy Kozári Monika müve méltó figyelemre tarthat számot a korszak, valamint a „szép akasztott ember” iránt érdeklődők legszélesebb körében.

(Kozári Monika: Andrássy Gyula. Budapest: Gondolat Kiadó, 2018, 224 o.)

Gali Máté tudományos munkatárs, VERITAS Történetkutató Intézet 


\section{ÍVEK ÉS TÖRÉSPONTOK}

A tanulmánykötetek a megismerés folyamatának fontos darabjai lehetnek. $\mathrm{Ha}$ új forrásanyagot hoznak felszínre, magvas elemzéseket tartalmaznak, vitás kérdésekben jól körvonalazott álláspont mellett meggyőzően érvelnek, vagyis van elméleti hozadékuk - és mindezek alapján majdani összefoglalások megbízható építőkövei.

A kezünkben lévő könyv ilyen írások tárháza. Az elsőt szerzője harminckét esztendős korában, 1984-ben publikálta. Azt a kérdést vizsgálja benne, hogy 1953-1956 között milyen változások történtek az iparvezetés gyakorlatában, azok milyen szerepet játszottak az 1968-tól beindult új gazdasági mechanizmus előkészítésében. Egyben ráirányítja a figyelmet arra, hogy a vizsgált évek megújítást célzó törekvései általában az „egyszerüsítés” szó jegyében zajlottak.

A kötet időben legutóbb született darabja oly’ friss, hogy másutt még nem publikáltatott. Aczél György és a kádárizmus kapcsolatait boncolgatja. Ennek okán is többről van szó, mint amit az Elöhang jelez. Mert nem egy negyedszá$z a d$, hanem bö három évtized válogatott tanulmányaiban tallózhatunk.

Időközben a szerző jelentős monográfiákat is az asztalra tett. Megjelenésekor, 1989-ben ugyancsak megkésettnek tünt a Hatalom és mozgalom, 1956-1989. Társadalmi-politikai erőviszonyok Magyarországon címü könyv. A feltornyosult áradattal szemben a létező szocializmus megreformálása mellett érvelt. Döntően messze nem a hazai történések három évtizede, sokkal inkább a világtörténelem e spáciumának alapfolyamatai mondatják, hogy az emberiség jövőjének felelősségével a páston egyedül maradt kapitalizmus nem megoldás. Itt vélhetőleg elegendő e vonatkozásban Thomas Piketty nevezetes munkájára utalnunk. Az 1995-ben megjelentetett következő munka, Az eladósodás politikatörténete, 1957-1986, jelentőségéröl önmagában a cím is sokat mond. A létezett magyarországi szocializmus egyik legnagyobb tehertétele az volt, hogy nem karolta fel a szórványmagyarság ügyét. Mert a rendszer Moszkva árnyékában, s jelentôs mértékben ideológiai vakságának kalodájában élt. Pedig már a Kommunista Kiáltvány szorgalmazza, hogy a munkásosztály nemzetté szerveztessék. Mégis a nemzetivel a baloldal többnyire ma is hadilábon áll. A legnagyobb tétel itt közismerten a magyar-román viszony. A Magyarország, Románia és a nemzeti kérdés, 1956-1989 című monográfiában feltárt anyag azt mutatja, hogy a kádári Magyarország a közgondolkodásban feltételezettnél többet tett e téren. Három év óta vehetik kézbe az érdeklődők a Kádár János külpolitikája és nemzetközi tárgyalásai, 1956-1988 címü opuszt. Ennek teljes második kötete a mondanivaló alátámasztásához legfontosabb dokumentumok 
gyüjteménye. A könyv címe is a szerző egyik igen lényeges, rokonszenves vonását mutatja: az ugyanis a ténylegesen teljesítettnél kevesebbet ígér. Hiszen más szerző könnyen adta volna e könyvnek a Magyarország külpolitikája vagy más hasonló címet.

A kezünkben lévő tanulmánykötet írásai és e könyvek természetesen szoros kapcsolatban élnek. Történelemszemléletük érthetően azonos. A honi világban ez sokaknak nem rokonszenves. Nincs ebben semmi baj, a pluralizmusnak lehet jó hozadéka. Aki tárgyilagosan olvassa ezeket a dolgozatokat, az elismeri a szerző azon a törekvését, hogy mondanivalóját az adott időpontban elérhető legnagyobb tudás birtokában, elfogulatlanságra törekedve adja elő. Ha olvasunk is nála sarkos megállapításokat, a vagdalkozástól távol tartja magát, állításai vitaképesek.

Az írások négy nagy fejezetbe kerültek. Az elsőnek Gazdaság és politika a címszava. Benne a magyar-szovjet gazdasági kapcsolatok kerek negyedszázadát áttekintő fundált dolgozat, valamint a már említett, iparvezetéssel foglalkozó írás található. A második fejezetet 1956-1957 kronológiája rendezi. Itt három írás található. A Nyikolaj Buharin és Nagy Imre párhuzamos drámájából „csak” Hruscsov egy alkalommal Nagy Imrének szegezett mondatát említjük. Amikor a magyar kommunista döntésre szólíttatott: a párttal vagy a párt ellen akar menni. Nagyot téved, aki itt csupán kommunista csalafintaságra gondol. Hruscsovból a mindenkori hatalom arroganciája beszél. A hatalom én vagyok. Vagy igazodsz, vagy eltaposunk. A párt a történelemben hol hazával, országgal, vallással stb. helyettesíttetik. És megy a verkli. Természetesen csak egy ideig. A bukásig.

A harmadik, legterjedelmesebb fejezet (hat dolgozattal) magától értetődően a kádárizmusé, $s$ természetesen a főszereplőé. Tegyük hozzá: az előző fejezet két említetlen írása is a kádári örökséget érinti, amely sok szempontból messze nem a hruscsovi receptet másolta. Földes történetírásának érdeme pedig ennek a dokumentálása. Itt található a kötetnek címet adó írás is. Ez esetben „csupán” a hajdanvolt főszereplő életére korlátozva. Tehát Ívek és töréspontok Kádár János politikai pályáján.

A záró fejezetben Földes György az eszmék és ideológiák világában való otthonosságát csillogtatja meg. Fontos dolgozat ad megszívlelendő szempontokat az államszocializmus legitimitáspolitikájához. A manapság szenvedélyes viták tüzében álló 1968-as esztendő generációhistóriáját a szerző két írásban is taglalja. Még a fordulat előtti idők lenyomataként született az a terjedelmesebb írása, amely az 1945-1983 közötti pártoktatási kézikönyvek szocializmusképét ismerteti. Találó főcímmel: A jövőtől a jelen felé. Ezen írások legihletettebbje a kitűnő Gáll Ernő baloldaliságát vizsgálja. Úgy, hogy nem kevesen saját szellemi vívódásaik tükrébe is nézhetnek. 
Az Elöhangban Földes György a jelenkorkutatás sajátosságaival és problémáival foglalkozik. A recenzens kitart azon régi álláspont mellett, melynek képviselöi számára az a döntő, hogy a kutatott korszak nyitott-e avagy lezárt a jelen nézőpontjából. A vizsgált kötet szempontjából pedig igen üdvösnek tartja, hogy tartalmának túlnyomó hányada az 1988. májusi pártértekezlet elötti időszakot búvárolja.

(Földes György: Ívek és töréspontok. Tanulmányok. Budapest: Napvilág, 2018, 368 o.)

Pritz Pál

történész 


\section{BONTAKOZÓ JELENTÉS}

A kötet több, mint egy szokásos évfordulós tisztelgés a pécsi egyetem pszichológiai arculatának egyik alakítója előtt. A negyvenegy tanulmány szakmai érdekességet is hordoz. A kollégák, munkatársak, követők és tanítványok dolgozatai többnyire esszéisztikus áttekintésben mutatják meg, milyen is a sajátos pécsi pszichológiai iskola, melynek szemléletét az ünnepelt és László János mellett a mai pszichológiában Erős Ferenc és Bereczkei Tamás képviselik.

A kötet néhány tanulmánya kifejezetten történeti igényü, s mint ilyen forrásként fog megmaradni. Balikó Márta Kézdy Balázs tanszékalapító szerepét vizsgálva megmutatja, hogyan kapcsolta össze a dinamikus szociálpszichiátria egyik hazai vezetője a klinikai és egyetemi szemléletet számos hálózat (lelki elsősegély, tanácsadás) és a tanszék közti kapcsolat megteremtésével. Vincze Orsolya az intézetet megszervező $\mathrm{s}$ a pécsi narratív pszichológiai hagyományt elindító László János szemléletét s hatását elemzi. A nemzetközi elismertség elérése mellett Lászlónak fontos érdemei voltak abban is, hogy Pécsett megteremtette a kapcsolatot a pszichológusok, irodalmárok, történészek és nyelvészek között. Éppen e kapcsolatteremtések miatt sajnálhatjuk, hogy a két „Pécs-történeti” munka távlataiból kimarad az 1992-1996 között dékán, kommunikációkutató Horányi Özséb és Grastyán Endre élettani iskolájának szerepe.

A kötetben vannak más történeti dolgozatok is. Forrai Márta alapos intézménytörténeti elemzésben mutatja be a hazai klinikai pszichológiai szakképzés formáinak történetét. Ehmann Bea a narratív pszichológia mủvelőjének szempontjából helyezi el a hazai törekvéseket a nemzetközi trendekben. A hazai nóvum itt a nyelvtechnológia bekapcsolása volt az elbeszélő szemléletű pszichológiába, aminek köszönhetően nagy alkalmazású érzelmi szótárak is születtek. Erős Ferenc az Amerikába emigrált újító pszichoanalitikusok, Erich Fromm, Bruno Bettelheim és Errik H. Erikson munkáiban mutatja meg az egyéni sors és a szakmai témák kapcsolatát.

A kötet egészét áthatja a ,pécsi szemlélet” néhány kulcsmozzanata, mely az ünnepelt, Péley Bernadette munkásságát is jól jellemzi. A hét nagyobb fejezetbe besorolt tanulmányok jól mutatják ennek a pécsi szemléletnek néhány alapvonását. A narratív szemlélet pécsi mintázata összekapcsolja a klinikai, a szociális és fejlődéslélektant. Néhány példa. Pohárnok Melinda óvodások érzelmi emlékeinek történeti szerveződéséről ír, B. Erdős Márta pedig a serdülő szerhasználók történeteiről, Vincze Orsolya és munkatársai a történeti emlékezet és az egyéni kognitív stílus kapcsolatáról, s számos dolgozat (Csókási Krisztina, Teleki Szidalisz Ágnes, Ihász-Écsi Júlia) a narratív elemzés közvetlen klinikai felhasználását mutatja be. 
A pécsi szemlélet másik jellemzője a kritikus korok elemzése, a korai kötődés alakulása és a serdülőkor kiemelése. A kötet érdekessége, hogy ezeket a jellemzőket váratlan kombinációkkal is bemutatják a szerzők. Czibor Andrea és Restás Péter a serdülökor beavatási rítusainak újramegjelenését elemzik a modern szervezetekben, Lábadi Beatrix a testkép jelentőségét tekinti át a korai identitás alakulásában.

A pécsi szemlélet jellemzöje a klinikai és a tipikus fejlődés elemzésének összekapcsolása, a klinikai fejlódéspszichológia is. Nagy László e keretben a narcisztikus személyiségzavar alakulásában mutatja be a gondoskodó szülő paradoxonait, azt, hogy a túlóvás hogyan vezethet narcizmushoz. Ajkay Klára a korai kötődés iránti hazai érdeklődésben mutatja be a fejlődéslélektani és klinikai érdeklődés egymásra találását.

Egészében a kötet sokaknak ad izgalmas olvasmányt. Miközben a pécsi iskola szemlélete irányítja, izgalmas kaleidoszkóp is marad.

(Bóna Adrien - Lénárd Katalin - Pohárnok Melinda szerkesztök: Bontakozó jelentés. Tanulmányok a 60 éves Péley Bernadette köszöntésére. Budapest: Oriold, 2017, 393 o.)

Pléh Csaba pszichológiatörténész 


\section{AZ EMLÉKEZÉS TÉTJE}

A tekintélyes idős tudós pályája összefoglaló korszakához érve visszatekint az életútjára? Öregember lett, aki nem müveli immár a maga tudományát, ehelyett emlékezést fogalmaz csupán: elmeséli az életét, személyes anekdotákat idéz föl, korábbi nagy müvei keletkezéstörténetének adalékait osztja meg érdeklődő olvasóival? Emlékezését fogalmazva pedig kicsit el is érzékenyül a saját nagyszerűségén: szobortalapzatot ácsol tehát magának, amire még életében elkezd fölmászni?

Nem, nem, Vajda Mihály esetében nem ilyesmiről van szó. Önéletrajza, a gyorsan az olvasói népszerüségi listák elökelő helyeire fölszökő Szög a zsákból, ez a zavarba ejtően müfajtalan, zavarosan befejezetlen és lehetetlenül izgalmas emlékirat, nem befejezi a filozófia müvelését - éppen az emlékezés filozófiáját igyekszik végiggondolni -, és nem szobortalapzatot ácsol, éppen az önfényezés bármiféle esetleges kísértésével való leszámolás jegyében készült. A kettő közül az előbbi a bonyolultabb, az utóbbi az egyszerübb kérdés.

Kezdjük tehát az utóbbival. Szobortalapzat-ácsolás, elérzékenyülés, önfényezés? Ha valami idegen a kötettől, ezek aztán tényleg azok. A hazai filozófiai közélet egyik legjelentősebb kortárs szereplője - nyolcvanon fölüli akadémikus-professzor -, úgy tünik, javíthatatlan hatvannyolcas maradt: következetesen nonkonform, mindig frivol, gyakran vulgáris. Ahogy hivatalos alkalmakon sem szívesen visel nyakkendőt, úgy emlékezésein dolgozva sem igyekszik emelkedettebb stílben fogalmazni. Tudatosan köznyelvi regiszterben tartott müve mondataiban többször tünnek föl közönségesként számon tartott kifejezések. Az első világháborúban orosz fogságba esett apja, meséli, egy nagy monarchiából indult el, és „egy picsányi kis országba érkezett vissza”. A hetvenhármas „,filozófus-perre" - a korszak kritikai gondolkodói ellen foganatosított adminisztratív pártintézkedésre - visszaemlékezve elárulja, ők, az elszenvedői bizony „csak-csak kiérdemelték a seggberúgást". Korai, Husserl és Lukács tudománykritikáját összevető cikkéről elismeri, hogy „rettenetes szar volt”. Husserl-kutatásainak kezdeteit fölidézve úgy fogalmaz, hogy „fingom se volt arról, hogy mi az, hogy Husserl”; korai Heidegger-ismeretét úgy minősíti, hogy annak idején „Heideggerből egy kurva szót se értettem". Kritikusi munkásságát értékelve pedig elárulja, soha nem írt negatív kritikát, sőt, általában a kritizált mü ,gyengeségeit sem emeltem ki soha a büdös életben". A visszaemlékező semmilyen posztamenst sem szemelt ki a saját szobrának, építeni meg aztán pláne nem szeretne egyet sem. Nyilvánosan gondolkodik mindössze: megkísérli megérteni önmagát, eltűnődik, mesél, fecseg, belemelegszik, itt-ott egyenesen trágár lesz. 
Az elöbbi, bonyolultabb kérdés Vajda filozófiafogalmához vezet. A szöveg szövevényében útnak induló olvasó itt nincs könnyü helyzetben: hogy tudniillik a visszaemlékező mit is gondol róla, voltaképp mi is a filozófia. A határozott állásfoglalás, a bizonyosságok megfogalmazása, a fogalmi szigorúság a visszaemlékezőtől általában is idegennek látszik. A kötet második egységének, a Kardos András-készítette életútinterjúnak a címe - A fontos, hogy amit állitok, ne legyen egyértelmü - igencsak árulkodónak minősíthető. Az egyértelmüségtől rettegö Vajda attól is ódzkodik, hogy saját tevékenységéről határozottan fogalmazzon. A gesztus nyilvánvalóan provokatív is: a személyiség, aki egész életét a filozófiának szentelte, ma a hazai filozófiai szcéna legjelentősebb alakjainak egyike, íme, azzal bosszantja az olvasót, hogy nem tudja, voltaképp mivel is foglalkozott-foglalkozik egész életében, azaz mi volna tehát a filozófia. Próbáljuk azonnal magunk elé képzelni - ugye, nem megy? -, mondjuk, a fizika idős akadémikus-professzorát, aki visszaemlékezésében bevallja, sejtelme sincs, miféle tudományt is mủvelt. A kötetben elszórt megjegyzések körülírják csupán a filozófia fogalmát. Ezeket összeolvasva, úgy tủnik, Vajda számára a filozófia valami olyasmi, ami inkább kérdés, semmint válasz; inkább beszélgetés, semmint monológ; inkább tevékenység, semmint teória; inkább elbizonytalanít, semmint megnyugtat; inkább a tisztánlátást kell segítse, semmint hogy vigaszt nyújtson. Mindenesetre, a mítoszból kinövő és a mítosszal szembeforduló európai kultúra önálló szellemi területe, amely semmiképp sem azonosítható és nem cserélhető föl a tudománynyal. Nem a megismerés, hanem az értelemadás a feladata. Mindösszesen: bizony, közelebb látszik állni az irodalomhoz, mint a tudományhoz.

Vajda visszaemlékező munkája innen tekintve sajátos filozófiai jelentést nyer. Nem a filozófiától független tevékenységnek látszik immár - olyasminek, amit a maga filozófiai munkálkodását lezáró bölcselő folytat, mondjuk, a maga időtöltéseként vagy olvasói szórakoztatására. Nem, éppen a filozófiai munkálkodás sajátos területeként körvonalazódik. A kései Nietzsche enigmatikus megállapítása szerint „,minden nagy filozófia” végső soron voltaképpen „szerzőjének önvallomása, s egyfajta akaratlan és észrevétlen memoár". Itt, ebben az önéletrajzban Vajda most nem idézi a mondatot; szorgalmas olvasói jól tudják pedig, hogy mostanában egyébként éppen ez a gondolat foglalkoztatja legintenzívebben. Az a posztmetafizikai filozófia, amit manapság művel, éppen ennek a gondolatnak a jegyében áll. A metafizikai filozófia valamiféle kizárólagos igazságot képviselő hatalmi beszéd volt, magyarázza, és az üres általánosságot fogalmazta meg csupán. A mai posztmetafizikai filozófia vele szemben a saját igazságát nem tekinti az egyedüli igazságnak, teszi hozzá, és az általánost valahogyan megérzékítő történeteket mesél el. A fogalmiságot a narratívitásba oldó új bölcselet pedig éppen ebben, az emlékezet munkájában találhatja meg a maga ugrópontját. Tegyük rögtön hozzá: most, tavaly zárult le Vajda életmüsorozata - a Kalligram Kiadó négy hatalmas, összességében több mint négyezer oldalra rúgó kötetben bocsá- 
totta közre a filozófus legfontosabb munkáit. A sorozat negyedik, zárókötetének - ennek az elmúlt jó évtized termését összegyüjtő opusznak - a címe pedig, figyeljünk föl rá, éppen a „személyes emlékezet filozófiájáról” beszél.

Az emlékezés tétje tehát: maga a filozófia. Amit Vajda itt, könyvének első fejezeteiben elkezd, bízvást bámulatosnak nevezhető. Emlékezetmunkát végez, nyilvánosság előtt fölmutatva a próbálkozásokat, ahogy a maga korai emlékeinek megidézésére indul. Megkísérli megragadni az emlékeit, finom elemzés alá vonva, hogy vajon miért, milyen elfojtások nyomán nem talál rájuk. Az emlékek fölidézési kísérlete nyomán pedig az első képekig hatol tovább: gyerekkora pillanatnyi látványait idézi föl, amik még jelentésük nélkül tolulnak föl benne, elbeszélésbe még nem foglalva jelennek meg előtte. A fogalmiságot megelőző és narrativitást nélkülöző képeket fogalmi alakra hozni és narratívába foglalni: Vajda egyszerre rebbenékenyen szubtilis és kíméletlenül radikális vállalkozása. Ahogy a képeket fogalmi alakra hozva és elbeszélésbe foglalva megkísérli megrajzolni előbb anyja, majd apja alakját, ahogy fölidézi saját gyerekkorát: valóban kiemelkedő gondolati - egyben irodalmi - teljesítmény.

Vajdáról az érdeklődő, ugye, azt tudhatja meg legelőször, hogy Lukács György tanítványa volt, a múlt század kiemelkedő bölcseleti mühelye, a Budapesti Iskola tagjaként indult el a pályáján; egyébként meg zsidó kispolgári családból származik. A két faktum jelentősége itt, ennek a memoárnak a lapjain megcserélödni látszik. A maga zsidósága - ez a korábban akcidentálisnak tűnő tényező - meghatározóvá emelkedik, Lukács és a Budapesti Iskola hatása - az indulás meghatározó mesterének és műhelyének jelentősége - ellenben mintha halványodni kezdene. Vajda, egyrészt, negyvennégyben kilencéves, a magyar vészkorszak történéseit már tudatos kisgyerekként éli meg tehát. Az emlékezet, ami eddig nem akart müködni, ettől kezdve élesen világos, határozottan értelemteli és narratívába szervezett képeket szolgáltat. A kisfiú sárga csillagot kap; családjával együtt csillagos házba kerül; nap mint nap lekolompolják a ház udvarára, ahonnan a kiszemelteket a Duna-partra hurcolják; tanúja lesz, amikor anyja és nagynénje összevitatkozik, nem kellene-e a gyerekeket vidékre menekíteni. A kisgyerek alig néhány hónap alatt fölnő és megöregszik; beleég saját másságának és alacsonyabbrendűségének, üldözöttségének és megsemmisíthetőségének a tapasztalata. A személyes emlékezet filozófusát éppen ez a traumatikus tapasztalat alakítja filozófussá. Vajda, másrészt, tudvalévő, Lukács köréből indul, a Budapesti Iskola gondolkodója lesz. Lukács a magyar filozófiai hagyomány kiemelkedően legjelentősebb alakja, a Budapesti Iskola a múlt század egyik legfontosabb hazai filozófiai csoportosulása. Itt, ebben a memoárban, ehhez képest Lukács inkább rokonszenves öregemberként tủnik föl, a Budapesti Iskola pedig szoros baráti körnek látszik. Lukács nem a vitatásra érdemes bölcseleti nézeteivel és vitatható politikai állásfoglalásával lép elénk: karizmatikus öregként, akit a visszaemlékező, mindennel együtt és mindennek ellenére, szeretni tudott. A Budapesti Iskola 
pedig erős rokonszenvekre épülő, ám határozottan érdektagolt és intrikáktól sem mentes csoportosulásnak látszik. Az eredetileg a marxizmus rekonstrukciójára szövetkezett iskola, tudjuk, a marxizmus dekonstrukciójához érkezik el. Megszüntét a visszaemlékező egyszerre éli meg fájdalmasan és fölszabadítóan: ahogy meséli, „megváltó eszme” és „filozófiai álláspont” nélkül marad ugyan, az iskola fölbomlását mégis valamiféle „megszabadulásként” tapasztalja meg, amelynek nyomán ,végre önmaga lehet".

A kötet, említsük meg róla végül, két hosszabb, nagyjából azonos terjedelmü egységből áll. Az első maga a - rövid, alcímekkel ellátott fejezetekre tagolt - viszszaemlékezés, a második Kardos András már röviden említett életútinterjúja, amelyik épp ott veszi föl a történet fonalát, ahol a visszaemlékezés elejtette. Öszszességében azt kell mondanunk, a visszaemlékezés első néhány fejezete egészen kiemelkedő, további fejezetei informatívak, az interjú hasonlóképp érdekes, müfaji státusza viszont tisztázatlan. Az első fejezetek, ismételjük, az emlékezetmunka rendkívüli teljesítményei: ahogy ezekben megképződnek a család és a kisgyerek emlékei, az a kortársi értekező próza egyszerre rendkívül finom és kiemelkedően erős darabjaivá teszi őket. A többi fejezet informatív, a hozzá nem értőnek érdekes, a hozzáértőnek kifejezetten izgalmas történetekkel szolgál, az emlékezés bölcseleti tétje azonban ezekben már mintha halványulni látszana. Hogy a szerzői szöveg a kötet közepén miért alakul át hirtelen interjúvá, nem tudjuk - nem is kérdeztünk utána -, a visszaemlékező talán belefáradt saját vállalkozásába, esetleg elunta az egészet, meglehet, egészségének megromlása akadályozta, hogy maga fejezze be müvét. Az interjúkészítő Kardos remekül tájékozott és kiválóan fölkészült beszélgetőpartner, ráadásul a visszaemlékező jó barátja. A folytatás ilyenformán azonos dinamikájú marad, ugyanolyan köznyelvi hangon szól, ugyanolyan szeszélyes gondolati kavargással halad. A beszélgetés szövege azonban - nyilván tudatosan, de nehezen magyarázhatóan - olyan szerkesztetlen, hogy a kötet két szövegegységének ez az elkülönülése kifejezetten furcsa hatást kelt. Az olvasót, a kötetet befejezve, akaratlanul is, a befejezetlenség érzete fogja el.

(Vajda Mihály: Szög a zsákból. [Tények és tanúk] Budapest: Magvetö Könyvkiadó, 2017) 


\section{A RÁKOSI-KORSZAK KÖNYVTÁRÜGYE}

Gyarmati György találó kifejezésével a „modernkori tatárjárás” - az 1945 és 1956 közötti Rákosi-korszak - Magyarország történelmének egyik legsötétebb, legfélelmetesebb időszaka volt. Rákosi regnálása alatt hazánk lényegében szovjet protektorátussá vált. A totális káoszt előidéző terroruralom óriási gazdasági és társadalmi veszteségeket okozott abban az országban, amely a megelőző években szinte felfoghatatlan emberveszteséget és hatalmas háborús károkat szenvedett el. A romba döntött országban fizikailag ugyan elkezdődött az újjáépítés, de a Rákosi-féle „pártegyeduralom” a megbékélés helyett a hidegháborús hisztériát szította. Elkezdődött a mezőgazdaság kollektivizálása, az erőltetett iparosítás. A lakosság napi tapasztalatává vált az államilag vezérelt jogfosztás, melynek következtében mindent átjárt a roppant hatékonyan müködő terrorgépezettől való félelem és rettegés.

A soha nem látott erőszakkal sulykolt kommunista ideológia feldúlta és szétzilálta a könyvtárak világát is. A területet irányító minisztérium már 1948-ban kijelölte a következő éveket meghatározó elveket: a könyvtári állomány nagy része időszerütlen tartalmú, azt a világszemléletet tükrözi, amely ellen harcot hirdettek, így ezeket a müveket a demokrácia nem adhatja „a nép kezébe”. Miután leginkább a könyvtárostól függ, mit olvas a város és a falu népe, ezért a könyvtárosok ,átnevelése" fontos, halaszthatatlan feladat.

A pártközpont Agitprop Bizottsága sietett kidolgozni a könyvtári tevékenységet meghatározó szempontokat, melyek élén a „munkásosztály és a dolgozó parasztság politikai öntudatának és kulturális színvonalának emelése, a marxista-leninista ideológia terjesztése" állt. A frissen létrehozott Népkönyvtári Központ raktáraiba óriási mennyiségü ,selejt könyvanyag" került - ez alatt föként a volt szerzetesrendi könyvtárakból kivont állományt kell érteni. A könyvek egy részét már zúzdába küldték, amikor néhány józanabb hang figyelmeztetésére felülvizsgálták a kiselejtezett állományt, és legalább a tudományos értéket képviselő műveket megmentették a bezúzástól.

Az 1949-ben megkezdődött szisztematikus selejtezés nemcsak a könyvekre, de a könyvtári szakemberekre is kiterjedt: ideológiai okokból számos diplomás könyvtárost távolítottak el az állásából. Alig pár év alatt a könyvtárak a pártpropaganda eszközeivé váltak.

Erről a vészterhes korszakról jelent meg az Országos Széchényi Könyvtár és a Gondolat Kiadó gondozásában a Fejezetek a magyarországi könyvtárügy történetéböl (1945-1956) címü könyv, amely fontos mérföldkő a hazai könyvtártörténet-írásban. A magyar könyvtártörténet legforrongóbb évtizedét bemutató kötet 
a szerkesztési munkálatokat is magára vállaló Sonnevend Péter, továbbá Kégli Ferenc, Pogány György, Pogányné Rózsa Gabriella és Varga Katalin tanulmányait tartalmazza. Ahogy a címe is utal rá, a szerzők nem a korszak teljes körü monográfiájának megírására, hanem az egyes szakterületek sajátosságainak bemutatására, elemzésére vállalkoztak.

A kötetben feldolgozott témák:

- Sonnevend Péter az 1944-1956 közötti időszak, a kultúrforradalom múvelődés- és könyvtárpolitikai kényszerpályáit tekinti át.

- Pogány György tanulmánya a világháború okozta károk feltérképezése után a politikai jellegű személyi tisztogatásokról, illetve a könyvtári állomány módszeres - az esetek nagy részében a könyvek megsemmisülésével együtt járó - selejtezéséről szól.

- A Rákosi-korszak urai a társadalom jövőjét befolyásoló stratégiai ágazatként kezelték a könyvtárosképzést. Pogányné Rózsa Gabriella a gyorstalpaló tanfolyamoktól a főiskolai végzettségig terjedő szakmai képzési rendszer kialakítását mutatja be.

- Rákosiék fontos nevelési eszköznek tekintették az iskolai és gyermekkönyvtárakat, amelyek müködését szintén új alapokra helyezték. Az e téren kidolgozott elvek helytállónak mondhatók - eltekintve attól, hogy a gyermekek számára kialakított gyüjteményeket igen egyoldalúan, csak szovjet irodalommal töltötték föl. E fontos szakterület helyzetének feldolgozása Varga Katalin nevéhez füződik.

- Nem egészen hét évig müködött a könyvtárakban folyó munka állami felügyeletét, ideológiai és szakmai irányítását ellátó Országos Könyvtári Központ (OKK). Az 1945 decemberében megalapított OKK létrejöttéről, múködéséről, majd 1952. évi felszámolásáról íródott Kégli Ferenc tanulmánya.

A korszak szakmai kérdéseit felölelő tanulmányok megírásához a szerzők számottevő mennyiségủ levéltári forrást dolgoztak föl. A magyar könyvtárügy meghatározó jelentőségű időszakát feldolgozó kötet az Országos Széchényi Könyvtár és a Gondolat Kiadó 2010-ben indult közös sorozatában, a Nemzeti tékában jelent meg. A könyv erényei között meg kell említeni a gondos közlést és a részletes apparátust, amely nagyrészt a szerkesztésben közremüködő és a pontos mutatókat összeállító Kégli Ferenc érdeme.

A szerkesztői bevezető számba veszi a későbbiekben feldolgozandó legfontosabb témákat, melyek a következők: a korabeli olvasó és az olvasási szokások vizsgálata, az egyes könyvtártípusok - legfőképp az egyházi könyvtárak, mellettük a tudományos, szak- és közkönyvtárak - története, továbbá a dokumentáció és a szolgáltatások kialakítása, valamint a könyvtárügy finanszírozása. Remélhetőleg a folytatás nem sokáig várat magára, és mihamarabb sikerül mindenre kiterjedően feltárni a magyar könyvtárügy e fontos korszakát. 
A maga nemében hiánypótló kötet megszületése nemcsak a hazai könyvtárügy szempontjából jelentős eredmény, értékes hozzájárulás a korszak társadalmi viszonyait feltáró munkálatokhoz. A helyrehozhatatlan károkat bemutató, tényfeltáró tanulmányok szikár, objektív stílusa kiválóan ellenpontozza a Rákosi-korszak rettenetét, és szembesíti az olvasót a közelmúlt döbbenetes valóságával.

(Sonnevend Péter szerkesztő: Fejezetek a magyarországi könyvtárügy történetéböl (1945-1956). [Nemzeti Téka sorozat] Budapest: Országos Széchényi Könyvtár-Gondolat Kiadó, 2018, 342 o.)

Tószegi Zsuzsa

címzetes egyetemi docens, ELTE BTK Könyvtár- és Információtudományi Intézet 


\section{A SZEGEDI Ö-ZŐ BESZÉDMÓD A 21. SZÁZAD ELEJÉN}

Ha van magyar nagyváros, amelynek mindenki számára nyilvánvaló nyelvhasználati jegye van, akkor az Szeged. Nemcsak Móricz Zsigmond regénye, a Rózsa Sándor miatt van ez így (bár vannak kétségeim, hogy sokan olvasnák a regényt). A mai szegediek egy részének napjainkban is hallható ö-zö, szögedies beszédmódja a fő ok. A bemutatandó könyv erről szól: mennyiben és hogyan ö-ző még Szeged a 21. század elején? A könyv az első városi nyelvi monográfia a magyar nyelvtudományban, amely szociolingvisztikai szemléletü, és módszerủ leírást ad - jelen esetben a szegedi ö-zésről és a vele összefüggő nyelvhasználati kérdésekrôl. A cím azért kívánt volna egy pontosító alcímet, mert az olvasók nagy része nyelvi leirás olvastán bizonyosan a szegedi nyelv grammatikai rendszeréról szóló leírást várna.

A vizsgálat anyagát 2013 és 2015 között gyüjtötték. 165 szociolingvisztikai interjú készült, 371 órányi digitalizált beszédfelvételt vizsgálhattak a szerzők. A szociolingvisztikai interjúk olyan strukturált kérdéssorokat tartalmaztak, amelyek a természetes társalgást utánozták. Precíz előkészületek, a vonatkozó hazai és külföldi szakirodalom alapos feldolgozása után alakították ki a szerzők módszertani eljárásaikat, s következetesen a szociolingvisztika variációelméleti keretében dolgoztak. Empirikus kutatást végeztek, megállapításaik nem intuíciós alapokon nyugszanak. Nyomatékos hangsúlyt kapott annak vizsgálata, hogy a szegedi társadalmi és szociokulturális körülmények hogyan befolyásolják a szegediek anyanyelvi nyelvhasználatát, hogy tehát mennyiben függ ö-zésük iskolázottságuktól, életkoruktól, müveltségüktől, szegedi identitásuktól - merthogy a „főhős” mindvégig a szegedi ö-zés volt. Egyik fő célkitűzésük adatközlőik metanyelvi tudásának, vélekedésének, ítéleteinek a vizsgálata volt abból a jól ismert társasnyelvészeti axiómából kiindulva, hogy az említett jelenségeknek a nyelvhasználat alakításában, tehát a beszélők rendelkezésére álló nyelvi változók közötti választásban nagy szerepük van. Tehát abban is, hogy mennyiben követik vagy nem szegedi anyanyelvtársaink az ö-ző beszédmódot, amely tudvalevően nem köznyelvi beszédmód (legyen bármennyire is szimpatikus a nem szögediek számára is). Magyarországon meglehetösen széles körben a nyelvjárási(as) beszédmód stigmatizálva van, s a diákok körében hat talán leginkább ez a vélekedés. Ezt állapíthatták meg a jelen könyv szerzői is, amit más szegedi forrásból is igazoltak: a „,szegedi diákok szerint a nyelvjárási beszéd »parasztos «, »idegesítő«, »régies«" (123.). Ilyen vélekedés mellett pedig nem könnyű kitartani a diáktársak között az ö-zés mellett. Az ö-zés visszaszorulására egy másik adat: a 20. század közepén az ö-zés még általános volt a szegedi iskolákban (125.). Várható volt, 
hogy nem lesz lényegi különbség sem az iskolatípusok (szakközépiskola és gimnázium), sem a nemek (lányok és fiúk) között (104.).

Számos részletkérdésben is többrendbeli tanulságot kínál az egyenletesen magas színvonalú szociodialektológiai munka. A terepmunkát akadályozó tényezők ebben az esetben is világossá teszik, mennyire fel kell készülnie annak, aki élőnyelvi gyűjtésre adja fejét. Laikus szemmel nézve kevéssé hihető, hogy csapdák várják a kutatót, ha megbízható adatokat akar gyüjteni. Pedig így van. Ezért éltek a szerzők azzal a lehetőséggel például, hogy igyekeztek ö-zve beszélő szegedi terepmunkásokat bevonni a gyüjtésbe. (A 19. század utolsó harmadában egy svéd dialektológus már-már elóírássá tette volna, hogy csak abban a nyelvjárásban érdemes gyüjtenie a nyelvjáráskutatónak, amelyet maga is beszél. Ez persze keresztülvihetetlen, hiszen akkor egyetlen nagyatlasz sem születhetett volna meg.) Meglepőnek tünik a megkérdezettek válaszadási hajlandóságának gyenge volta és a visszautasítások aránya. De ez is a mai valóság, amelyet más terepmunkai tapasztalatok is (például az új magyar nyelvjárási atlasz gyűjtőié) igazolnak.

A szegediek érzékelik az ö-zés tekintetében megmutatkozó nyelvhasználati különbségeket, s az ö-zés mint identitásjelző tényező alapján „osztályozzák” is társaikat, emígyen: szegedi ö-zők, gyüttmönt ö-zők, szegedi mekegők, gyüttmönt mekegők (mekegő = nem ö-ző, hanem e-vel beszélö ember). Mondhatjuk: világos beszéd. A tanulókkal kapcsolatos egyik megállapítás szerint a nem született ö-ző beszélők nem képesek a szegedi nyelvre jellemző ö-zést produkálni (111.). Ez azt jelenti, hogy az ö-zés jövője elsősorban a családokon múlik, azon tehát, lesznek-e gyerekek, akik az ö-zést is magukkal hozzák majd családi környezetükböl.

Jóllehet Szegednek környezete miatt erős a nyelvjárási beágyazottsága, nem meglepetés, hogy a szegedi ö-zés mind pragmatikai értelemben (az ö-zés társadalmi elterjedtségének, használati körének a tekintetében), mind nyelvrendszertani értelemben (a regionális sajátosságok vitalitását tekintve) a visszaszorulás, a térvesztés jeleit mutatja. Bölcsen tették a szerzők, hogy nem bonyolódtak jóslásokba az ö-zés jövőjét illetően. A nyelvi változások előre ugyanis nem jelezhetők megközelítő pontossággal sem (a nyelv szabályai és a fizika törvényei közé minden hasonlóságuk ellenére sem tehető egyenlőségjel). Fontos megállapítás, hogy „vannak olyan kitüntetett időszakok az egyén nyelvi életútjában, amelyek hirtelen, ugrásszerü változásokat eredményezhetnek a beszélő nyelvhasználatában és nyelvi attitüdjeiben" (197.). Ha ezeket az időszakokat jobban górcső alá vesszük, ha tehát a beszélők nyelvi tudatában (beleértve nyelvi attitüdjeiket is) bekövetkező változásokról többet tudunk, akkor az ezektől indukált nyelvhasználati-nyelvi változások megértéséhez és magyarázatához is közelebb férkőzhetünk - újabb lökést adva a diakrón nyelvi vizsgálatoknak is. A szerzők úgy vélik, hogy a szóban forgó impulzusok fő forrásai az iskolarendszer közvetítette hatások, amelyek egyrészt a pedagógusok részéről, másrészt a tanulótársak irányából érik a ta- 
nulókat. Kérdés, vajon mennyi szerepe van az egyre jobban globalizálódó világ informatikai környezetének, tehát a mediális hatásoknak.

A kötet jól mutatja a nyelvhasználat szociolingvisztikai vizsgálatának a vonatkozó területen sikert garantáló alkalmazását. A szerzők alaposan körüljárják és többoldalúan mutatják be a szegedi ö-zés széles társadalmi és nyelvi kontextusát, s utalnak a kutatási eredmények alkalmazásának, hasznosításának bizonyos lehetőségeire is.

(Kontra Miklós - Németh Miklós - Sinkovics Balázs: Szeged nyelve a 21. század elején. Budapest: Gondolat Kiadó, 2016, 295 o.)

Kiss Jenő

az MTA rendes tagja 


\section{A SIKER MEGSZELIIDÍTÉSE}

Kivel ne fordult volna már elö, hogy értetlenkedve figyelte, mitől tehetett szert valaki vagy valami széles népszerüségre és ismertségre, miközben másokat alkalmasságuk ellenére is messzire került a siker. A digitális világnak és a közösségi hálózatoknak köszönhetően pedig az elmúlt években mintha mindez hatványozottan igaz lenne. Mitől függ, hogy egy-egy hír, kép vagy gondolat vírusként söpör-e végig az interneten? Minek köszönhetö, ha a közösségi finanszírozást megcélzó projektek kampányai néhány nap alatt a célösszeg sokszorosát teremtik elö, miközben hasonlóan ötletes projektek észrevétlenek maradnak? Hogyan döl el, hogy melyik cikk vagy tanulmány vált ki komoly visszhangot a tudományos közösségből, és melyik merül a feledés homályába? Mindeddig aligha gondolhattunk mást, mint hogy a siker szeszélyes istenség.

Barabási Albert-László magyarul és angolul egyidőben megjelent $A$ képlet: A siker egyetemes törvényei címü könyvében arra vállalkozik, hogy a tudomány törvényszerüségeivel zabolázza meg a szeszélyes sikert. A kötetben Barabási a siker öt törvényén vezeti végig az olvasókat, amelyeket a saját kutatócsoportja és mások eredményeivel támaszt alá. Ezekhez a tézisekhez érdekes adalékkal szolgálnak a könyv tíz fejezetében leírt történetek, tudományos anekdoták, amelyek nem csupán az egyes törvények gyakorlati múködését világítják meg, de az ezekhez elvezető tudományos kutatások fordulataiba is beavatják az olvasót.

Barabási a „siker tudományának” nevezett terület bemutatását a siker meghatározásával kezdi, ami indokolt, hiszen a szót a hétköznapi nyelvben sokféleképpen értelmezhetjük. Barabási sikerdefiníciója a siker közösségi jellegére koncentrál: bár elismeri, hogy egy olyan mű létrehozása is okozhat sikerélményt, amit az alkotóján kívül senki sem lát, a könyvben a sikerrel csak mint társas elismeréssel foglalkozik. Ez pedig kifejeződhet jövedelemben, ismertségben vagy bármi másban, ami végső soron egy hálózat kapcsolataiként is értelmezhető. E definícióból szinte adódnak a könyv fö kérdései, amelyekre valamilyen módon mind az öt törvény reflektál: hogyan függ össze a teljesítmény és a siker; hogyan jósolható meg, és mitől függ a jövőbeli siker?

Barabási első törvénye szerint a sikert a teljesítmény határozza meg - de csak akkor, ha ez jól mérhető, mint például az egyéni sporteredmények esetében. Ha viszont a teljesítmény nem vagy nehezen ítélhető meg objektíven, a sikert a hálózati mechanizmusok határozzák meg. Ez a helyzet például a múvészi alkotások esetében és részben a szellemi alkotások, így a tudományos eredmények esetében is. Az emberi teljesítményt vizsgálva a szerző felhívja rá a figyelmet, hogy tulajdonságaink többsége normális eloszlást követ, vagyis kevesen és arányaiban 
kis mértékben térhetünk csak el az átlagtól. Ebből adódóan gyakran elóáll olyan helyzet, amikor az emberi teljesítőképesség határait súroló kiválóságok között kellene különbséget tenni, ez pedig - ahogyan a könyv néhány meggyőző példán keresztül szemlélteti - még a szakemberek számára is szinte lehetetlen. Ezekben a helyzetekben ismét csak a hálózatok és egyéb körülmények határozzák meg a siker mértékét.

A hétköznapokban a siker érthetetlenségének és kiszámíthatatlanságának látszatát éppen az a második törvényben rögzített összefüggés kelti, ami szerint a teljesítmény korlátos, a siker azonban korlátlan. Vagyis, a közösségi elismerés pénzben, figyelemben, ismertségben kifejezett mennyisége szinte bármekkora lehet, miközben az emberi teljesítmények között - épp ezek normális eloszlásából adódóan - többnyire legfeljebb néhányszoros szorzó jelenik meg. Mérő Lászlót megidézve mondhatjuk, hogy a teljesítmény ,átlagisztánban” áll elő, a sikert viszont „extremisztánban” mérik. Ezt a mechanizmust erősíti a „gazdagabb gazdagabbá válik", vagyis a preferenciális kapcsolódás elve, ami a sikereseknek több sikert juttat, s így az élet minden területén „szupersztárok” megjelenéséhez vezet. Az Újszövetség után Máté-effektusnak is nevezett jelenség (Máté 25:29 „Mert mindenkinek, a kinek van, adatik, és megszaporíttatik; a kinek pedig nincsen, attól az is elvétetik, a mije van") mellett némi vigaszt jelenthet, hogy Barabási harmadik törvénye szerint a jövőbeni siker nem pusztán a múltbeli sikerből, hanem ennek és a minőséget, rátermettséget is magában foglaló alkalmasságnak a szorzataként áll elö. Sem az elismertség, sem az alkalmasság nem elég tehát önmagában, mindkettőre szükség van a következő nagy sikerhez.

A könyvben szereplő egyik legmeglepőbb állítás, amit tudósok és alkotók ezreinek életpályája alapján vont le a szerző és kutatócsoportja, hogy a rátermettség, vagyis egy ötlet sikerre vitelének képessége (amit Barabási Q-faktornak nevez) egy-egy személy és téma viszonylatában az időben állandó. Vagyis például egy kutató képessége arra, hogy sikerre vigyen egy felfedezést, nem változik kezdő éveitől a pályája csúcsáig, sem pedig a későbbiekben. A siker azonban itt is egy egyenlet eredményeként, azaz a Q-faktor és egy-egy ötlet értékének (r) szorzataként írható fel. Ha tehát hiszünk az adatoknak, és elfogadjuk, hogy Q az időben állandó, ebből egyenesen következik Barabási ötödik törvénye: ha a Q-faktorunk megfelelő (tehát nem vagyunk alkalmatlanok saját területünkön), minél produktívabban dolgozunk, és minél több ötlettel állunk elö, annál nagyobb esélyünk van arra, hogy ezek közül valamelyik komoly sikert hoz számunkra.

A könyv erénye, hogy nyelvezete és a szöveg felépítése könnyen befogadható, olvasmányos, így a téma iránt érdeklődő széles közönség számára is fogyasztható, szakmailag mégis megalapozott. Az az olvasó ugyanakkor, akit a hálózatok világához, a közgazdaságtanhoz vagy a szociológiához komolyabb szakmai érdeklődés füz, a könyv végén, a jegyzetek között megtalálhatja a törzsszövegben hivatkozott kutatások alapján készült tudományos publikációkat is. A képlet ered- 
ményes kísérlet a siker megszelídítésére: néha szinte kézenfekvőnek tűnő, mégis hiteles, tömör és egyszerü állításokat fogalmaz meg a kutatások eredményei alapján. A siker törvényei éppen annyira elegánsak, amennyire ezt a társadalom „természeti törvényeitől” elvárhatjuk.

(Barabási Albert-László: A képlet. A siker egyetemes törvényei. Budapest: Libri Kiadó, 2018, 280 o.)

Baksa Máté

doktorandusz hallgató Budapesti Corvinus Egyetem Gazdálkodástani Doktori Iskola 